\title{
The impact of education and experience on profit of smallholder dairy farming at Batu City of Malang Raya, Indonesia
}

\author{
Hari Dwi Utami ${ }^{1, *}$, MB Hariyono ${ }^{1}$, Umi Wisaptiningsih ${ }^{1}$, Hary Nugroho ${ }^{2}$, and Nur Cholis ${ }^{2}$ \\ ${ }^{1}$ Department of Livestock Socio-Economic, Faculty of Animal Science, Universitas Brawijaya, \\ Malang 65145, Indonesia \\ ${ }^{2}$ Department of Animal Production, Faculty of Animal Science, Universitas Brawijaya, Malang \\ 65145 , Indonesia
}

\begin{abstract}
The research was conducted at Batu, City, Malang Raya of Indonesia. Study addressed to examine the farmer characteristics, dairy farming income, and the factors influencing on profit. The case study applied multistage sampling method to select 34 representative farmers which divided into three strata namely, stratum-1 (rearing $<4$ Animal Units), stratum-2 (owning 4-8 AU), and stratum-3 (controlling $>8 \mathrm{AU}$ ). Primary data collection used survey method with structured questionnaire, whereas secondary data were available in related institutions and sources. Data analysis implemented descriptive and multiple regression technique. Results confirmed that farmers has experienced about 6-10 years in raising dairy farming and they has secondary school education. The profitable dairy farming was smallholder dairy farming that rearing more than $8 \mathrm{AU}$ with daily income per Animal Unit of IDR 64,554 and structured with IDR 11,131 of revenue and IDR 47,577 of production cost. Farmer's experience was positively explaining the smallholder dairy profit, and the high school education attainment was more likely to increase venture's income. The farm return has positive and strong relationships with the more number of dairy cattle owned.
\end{abstract}

\section{Introduction}

Dairy farming was popular in rural areas as the favorable activity that can generate family income. As the growth of dairy farming, more family members has more participated in this farming and therefore it can contribute on family prosperity. In regard to dairy farming livelihood, previous studies discovered that this farming become imperative for villager livelihood since it can provide daily earning from selling fresh milk. This venture represents as prospective farming and contributes the good income for farmers' household [1]. Particularly, in the area where land holding is inadequate and unbalanced and therefore, smallholder dairy farming might become an alternative income enhancement [2]. Farmers who kept 3-5 AUs can contribute about 39\% to household Income [3]. Profit of dairy cattle

\footnotetext{
*Corresponding author: hrdwutami4@ub.ac.id
} 
per Animal Unit in monthly basis was about IDR 767,271 R. D. Haloho, et al.. [4], IDR 166,667/AU/month in West Java [5]. Study in in Budur Province of Turkey found net profit USD 188.28/AU/year [6].

Some previous studies ascertain that farmer's education and experience in rearing dairy has impacted on increasing dairy farming practices [7]. The diminishing technical inefficiency for milk production will related significant with the years of education [8]. Education of household head negatively affects technical inefficiency of milk production but, positively influence it as found in $[9,10,11]$.

The presence of faster technology development can offer potential tools that related to increase milk productivity, and therefore lead to dairy income. The proper application of technology might promise the higher milk production. IOT is one of the implementation in industry 4.0. Farmer's experience or knowledge of farming were more likely to accept the modern dairy farming in which implementing modern ways of treating farm animals [12]. Also, the adoption of advance technology have a positive relationship with the profit. The farmer that have good education only can capable using the advance technology. The research will try to insight into the influence of these variables in pursuing technology, either the have similar or opposite direction in regard to dairy farming income. Hence, the study addressed to three questions: (i) what is farmer's characteristic, (ii) how much profit will be obtained from dairy farming and (iii) what is factors explaining the venture income? Two hypothesis were formulated to answer the research objectives. Hypothesis-1: It was predicted that farmer's experiences in rearing dairy cattle has positively influenced on farming profit. Hypothesis-2: It was predicted that farmer's education was positively effecting on farming income.

\section{Materials and methods}

The research located in Malang Raya which selected by purposive sampling. The research was conducted at Batu, City, Malang Raya of Indonesia. Study addressed to examine the farmer characteristics, dairy farming income, and the factors influencing on profit. The case study applied multistage sampling method to select 34 representative farmers which divided into three strata namely, stratum-1 (rearing $<4$ Animal Units), stratum-2 (owning 4$8 \mathrm{AU}$ ), and stratum-3 (controlling $>8 \mathrm{AU}$ ). Primary data collection used survey method with structured questionnaire, whereas secondary data were available in related institutions and sources. Three analysis was done to analyse the data. First, descriptive analysis was important to perform the farmer's characteristics. Second, descriptive analysis using economic formulation is employed to analyse the farming return. Finally, the multiple regression technique might appropriate to explain factors influence on dairy farming income.

\section{Results and discussion}

In general, farmers has experienced about 6-10 years in controlling dairy farming which majority $(60 \%)$ was represented by farmers in stratum-2 (Figure-1). It implied that farmers has many solutions in dealing with various problems in operating dairy farming. Therefore, this farm can be maintain and sustain this farm in order to provide daily income for their family for long time. 


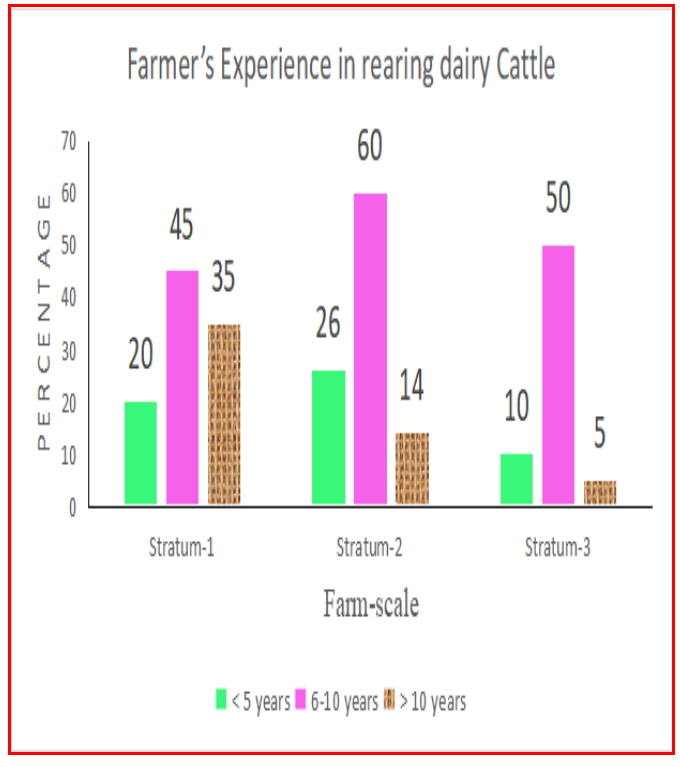

Figure 1. Farmer's experience in rearing dairy cattle

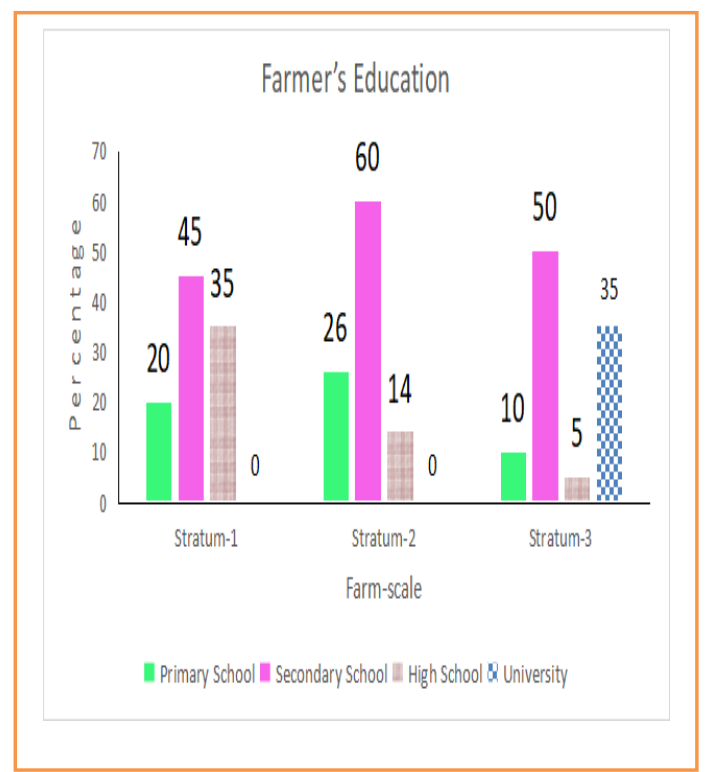

Figure 2. Farmer's Education

Figure 2 depicted that secondary school has dominated in all strata of dairy farming. Particularly, farmers in stratum-2 showed high percentage $(70 \%)$ in the secondary school attainment than those stratum-3 (50\%) and stratum-1 (45\%). The education will be related to the capability in access new technology and even easy to adopt them in running dairy farming. Hence, farmers can improve their skill in dairy farming practice to increase farm's productivity that resulting in high income achievement.

\subsection{Variable and Fixed Costs of Smallholder Dairy Farming}

Daily production cost per Animal Unit ranged IDR 43,617 -IDR47,577 with the efficient cost was coming from stratum-1. The expenses structured with $11.94 \%-14.79 \%$ for fixed cost (Figure-3) and $85.26 \%-85.89 \%$ variable cost (Figure 4). The efficient of fixed cost can reach in stratum-2 about $11.94 \%$, while stratum-3 was thriftily on the variable expenses up to $85.26 \%$.

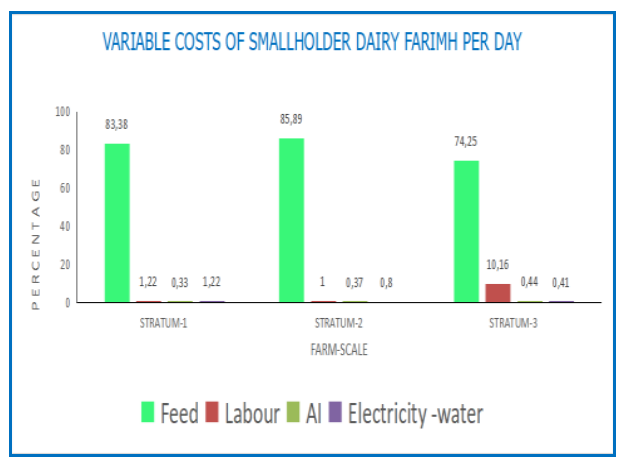

Figure 3.Daily variabel cost per Animal Unit of dairy farming

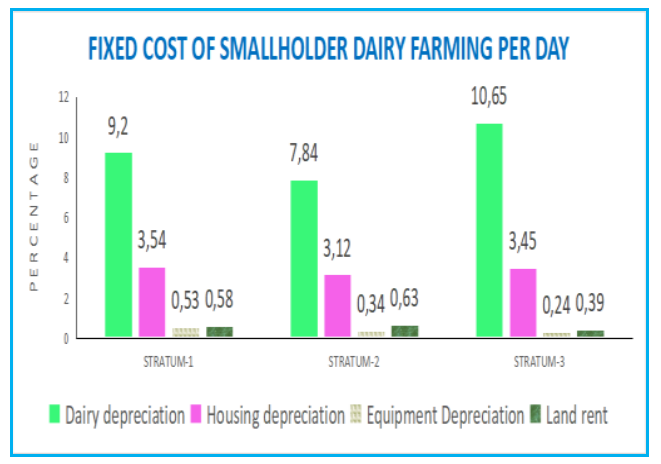

Figure 4. Daily fixed cost per Animal Unit of dairy farming 
Concerning to fixed cost, dairy depreciation in stratum -2 used the little depreciation costs $(7.84 \%)$ than those of stratum-1 (9.20\%) and stratum-3 (10.65\%). Likewise, the less fixed expenses happened in stratum-2 was about $3.12 \%$ in the comparison with stratum-3 $(3.35 \%)$ and stratum-1 (3.54 \%). Variable cost has counted lowest in feed concentrate expenses for stratum-3 (74.25\% in comparison with stratum-1 (83.38\%) and followed by stratum-2 (85.89\%).

\subsection{Revenue and Profit of smallholder dairy farming}

The revenue of smallholder dairy farming increase as the adding number of dairy cattle (Figure 5). The daily revenue per Animal Unit started from IDR 9,931 for stratum-1 to IDR 99,978 for stratum-2 and reached the highest one about IDR 112,131 in stratum-3. The revenue of stratum-3 composed with $64.11 \%$ from selling fresh milk structure for stratum2 , whereas and $35.89 \%$ from calf yielding. Selling fresh milk dominated $(69.12 \%)$ revenue structure for stratum-2 compared those from stratum-1 $(65.12 \%)$. It was small different the calf revenue between stratum-2 (30.88\%) and stratum-1 (34.88\%).

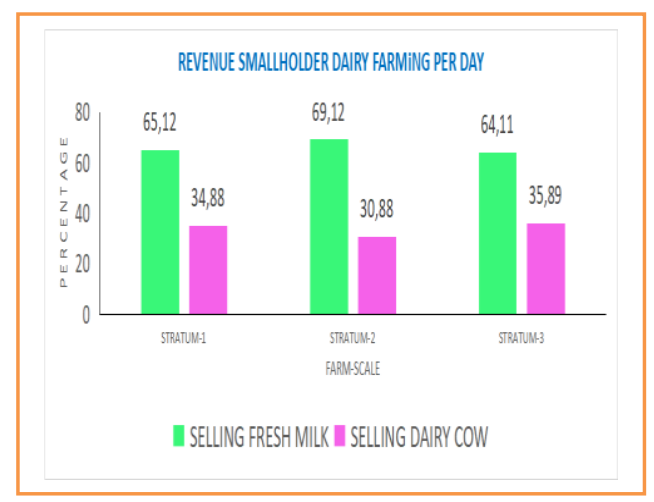

Figure 5.Daily revenue per Animal Unit of dairy farming

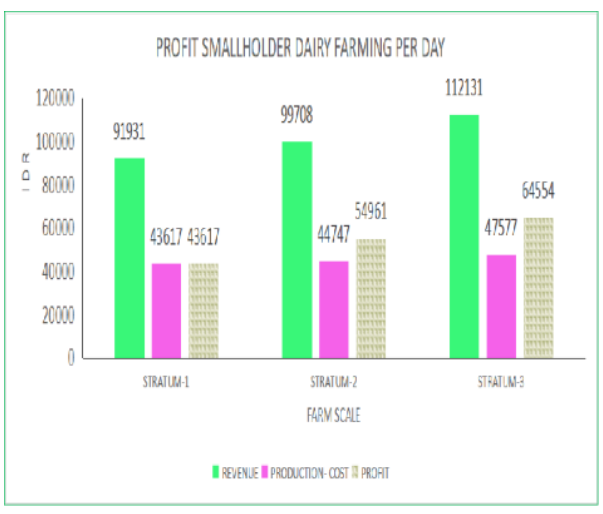

Figure 6. Daily profit per Animal Unit of dairy farming

Figure 6. exhibits the incline of daily Profit per Animal Unit aligning with the increase of the number of dairy cattle owned. The higher profit occurred on stratum-3 (IDR 64,554 ) in comparison with those for stratum-2 (IDR 54,961) and stratum-1 (IDR 43,617). The finding was highest than IDR 25,576 daily income per Animal Unit [4]. Smallholder dairy farming represented the prospective smallholder dairy farming in contributing the good income for farmers' household [3] and it might become an alternative in generating income in rural areas [2].

\subsection{Factors explaining smallholder dairy farming income}

Three of the six predicted variables can explain the profit of smallholder dairy farming (Table 1.). Coefficient determination (R2) was counted for $81 \%$. It can be interpreted that six predictor variables explain about $81 \%$ of smallholder dairy farming income, whereas the rest of $19 \%$ was clarified by other variables.

F-test addressed to examine the influence of all variables dependent toward dependent variable. F-calculation was 32.41 and very significant $(\mathrm{P}<0.000)$. Results informed that six variables namely farmer's age, education, experience in raising dairy, number of household 
members, land occupation and number of dairy cattle together had simultaneously affect on farming income.

Table 1. Factor influencing in Smallholder Dairy Farming

\begin{tabular}{|l|c|}
\hline \multicolumn{1}{|c|}{ Explanation } & Regression Coefficient \\
\hline Constant & 33.14 \\
\hline Age & 0.469 \\
\hline Farmer's Education & $-0.238^{*}$ \\
\hline Family number & -0.329 \\
\hline Dairy number & $1.126^{* * *}$ \\
\hline Land occupation & 0.256 \\
\hline Farmer's experience in raising dairy & $0.337 *$ \\
\hline $\mathrm{R}$ Adjusted $=74 \%$ & \\
\hline $\mathrm{R}$ Square $(\mathrm{R} 2)=81 \%$ & \\
\hline $\mathrm{n}=34$ & \\
\hline Fcalculation $=32.406$ & \\
\hline$* \mathrm{P}<0.01 ; * * * \mathrm{P}<0.000$ & \\
\hline
\end{tabular}

The result of t-test showed that three of six predicted variables were significantly having effect on farmers income. There were dairy number and the experience have positive influenced, whereas it was negatively affecting on farm income. The t-test shows that only three variables, experience and the number of dairy cattle were found significant positively influencing in dairy farming income, while it was the negative impact on farmer's education. The detail explanation will find in the following paragraph.

Dairy cattle number explains positively and very significant $(\mathrm{P}<0.000)$ in regard to farming return. Regression coefficient was 1.126 . It can be interpreted that the increase 1 unit of dairy number will raise profit 1.126 unit of profit. Likewise, study of H. D. Utami, et al. [1] reported that the more dairy owned, the many profit will be obtained. Smallholder dairy farming, therefore, become an alternative in generating income in rural areas [2].

Farmer experience in operating dairy farming has positive and significant $\mathrm{P}<0.01$ ) in relation with dairy profit. The results has accepted Hypothesis-1: It was predicted that farmer's experiences in rearing dairy cattle has positively influenced on farming profit. Regression coefficient was 0.337 . It can be interpreted that the incline 1 unit of dairy number will increase profit about 0.337 unit. Farmers have experienced long time about 610 years in operating their farm, therefore they have ability to deal with any problem in raising dairy cattle. This finding was aligning with study of Fita, et al. [7] that farmer's experience in rearing dairy has impacted on increasing dairy farming practices.

However, the farmer's education has negative and significant $(\mathrm{P}<0.01)$ impact on dairy return. The secondary school education of farmers will reduce the farm earning. In other words, the farm income will increase as the farmers has the high school education attainment. This discovering was agreeing with hypothesis-2: It was predicted that farmer's 
education was positively effecting on farming income. Regression coefficient was 0.238 . It can be interpreted that the raising 1 unit of farmer's education will improve farming income about 0.238 unit. This finding confirmed with the study of H.Girma, Heliyon [8] in that the diminishing technical inefficiency for milk production will related significant with the years of education. Therefore, education of household head positively affects technical efficiency of milk production [11].

\section{Conclusion}

The research has confirmed that farmers has experienced about 6-10 years in raising dairy farming and they has secondary school education. The profitable dairy farming was smallholder dairy farming that rearing more than 8 AU with daily income per Animal Unit of IDR 64,554 and structured with IDR 11,131 of revenue and IDR 47,577 of production cost. Farmer's experience was positively explaining the smallholder dairy profit, and the high school education achievement was more likely to increase venture's income. The farm return has positive and strong relationships with the more number of dairy cattle owned

It was suggested that the utilisation of qualified forage need to be improved to increase milk productivity. Farmers need to improve the clean and healthy environment to obtain the good quality, safety, and healthy milk products.

\section{References}

1. H. D. Utami, U. Wisaptiningsih, H. Nugroho, Laporan Penelitian (2018)

2. O. M. Kocturk, J Anim Vet Adv 8, 1685-1688 (2009)

3. H. D. Utami, A. P. Seruni, The 2nd Animal Production International Seminar (APIS) 2013 : Sustainable Livestock Production Based on Local Resources in the Global Climate Changes Era Prospect and Challenges (Universitas Brawijaya, Malang, Indonesia, 2013)

4. R. D. Haloho, S. I. Santoso, S. Marzuki, Jurnal Pengembangan Humaniora 13, 65-72 (2013)

5. K. S. Mudikdjo, R. Pambudy, Media Peternakan 24, 57-66 (2000)

6. V. Demircan, T. Binici, H. Koknaroglu, A. Aktas, Czech J. Anim. Sci. 51, 8-17 (2006)

7. Fita, M. M. Trivedi, B. Tassew, J. Agric Extension Rural Dev. 4, 69-78 (2012)

8. H. Girma, Heliyon, 5, 1-24 (2019)

9. Bardhan, Sharma, Springer Plus 2, 1-7 (2013)

10. Z. Adane, K. Shiferaw, B. Gebremedhin, International Livestock Research Institute (ILRI) 11, 1777-1786 (2015)

11. A. Al-Sharafat, J. Agric. Sci. 5, 45-53 (2013)

12. B. K. Boogaard, B. B. Bock, S. J. Oosting, J. S. C. Wiskerke, A. J. van der Zijpp, J Agric Environ Ethics 24, 259-282 (2011) 